\title{
MANAJEMEN SUMBER DAYA MANUSIA DALAM PENINGKATAN MUTU PENDIDIKAN DI PERGURUAN TINGGI
}

\author{
Oleh : \\ Kadek Hengki Primayana \\ Mahasiswa Program Studi Magister Pendidikan Dasar Undiksha
}

\begin{abstract}
Human resources management is very important in improving the quality of education. With the support of qualified resources, the university can go forward and develop. Improving the quality of education is determined by the leadership of educational institutions in managing their human resources. In the management of human resources, university leaders be key in improving the quality of education. University leaders are required to always develop human resources to create quality education.
\end{abstract}

Keywords: Education, Quality, Human Resources

\section{PENDAHULUAN}

Ekspektasi masyarakat terhadap dunia pendidikan semakin meningkat. Pada saat ini perguruan tinggi didorong untuk lebih berkontribusi terhadap peningkatan daya saing bangsa dengan melaksanakan pendidikan tinggi yang bermutu. Dalam mewujudkan pendidikan yang bermutu, berbagai upaya telah dilakukan oleh pemerintah maupun berbagai pihak lainnya. Penyusunan Undang-Undang Pendidikan Tinggi Tahun 2012 dan Peraturan Pemerintah turunannya, penyusunan dan penetapan Standar Nasional Pendidikan Tinggi serta pembentukan Perguruan Tinggi Badan Hukum merupakan beberapa upaya yang dilakukan oleh pemerintah untuk meningkatkan mutu pendidikan di perguruan tinggi. Tidak hanya pemerintah, perguruan tinggi juga melakukan upaya-upaya peningkatan mutu pendidikan tinggi diantaranya melalui peningkatan kualifikasi dosen dan tenaga kependidikan serta implementasi sistem penjaminan mutu internal.

Perguruan tinggi sebagai suatu lembaga pendidikan tinggi, dalam aktivitasnya diwajibkan melakukan peningkatan kualitas yang dapat diwujudkan melalui pelaksanaan pendidikan bermutu. Pendidikan dapat dikatakan bermutu jika dibuat secara sederhana tetapi penting dan memenuhi standar. Artinya, produk tersebut harus tepat sesuai dengan tujuan. (Susanti, 2013). Masih menurut Susanti (2013), pada dasarnya mutu pendidikan dapat dipandang sebagai suatu keadaan, kondisi, penampilan, atau kinerja yang ditunjukkan oleh setiap komponen satuan pendidikan dalam mencapai tujuan yang telah ditetapkan. Pada perguruan tinggi, peningkatan mutu pendidikan menjadi efektif apabila setiap pengambil kebijakan ikut berperan aktif dalam mengarahkan perbaikan tersebut. Maka daripada itu pimpinan perguruan tinggi memiliki peran yang sangat penting dalam peningkatan mutu pendidikan di lembaga pendidikannya.

Hal yang paling penting bagi pimpinan perguruan tinggi adalah meningkatkan kualitas dan mutu pendidikan di perguruan tinggi yang dipimpinnya. Dan perbaikan manajemen merupakan langkah awal menuju kualitas dengan pilar utamanya adalah kepuasan pelanggan, perbaikan berkelanjutan serta menghargai sumber daya manusia. Didalam 
suatu organisasi termasuk di perguruan tinggi, sumber daya manusia menjadi asset yang paling penting dan berharga. Pengelolaan sumber daya manusia di perguruan tinggi seharusnya sama dengan pengelolaan sumber daya manusia di perusahaan, tetapi karena karakteristik organisasi perguruan tinggi yang sedikit berbeda dengan perusahaan sehingga menyebabkan bisa terjadi sedikit perbebedaan dalam pengelolaannya. Dalam melaksanakan kegiatan organisasinya, perguruan tinggi dibatasi oleh berbagai aturan dan standar yang hasrus dipenuhi, seperti standar pendidikan tinggi, Undang-Undang Pendidikan Tinggi, dan yang lainnnya.

Dari berbagai hal itu tersebut maka manajemen sumber daya manusia menjadi hal yang sangat menarik, dikarena sumber daya manusia merupakan hal yang sangat penting di perguruan tinggi dalam upayanya untuk meningkatkan mutu.

\section{PEMBAHASAN}

\subsection{Sumber Daya Manusia}

Sumber daya manusia adalah kemampuan terpadu dari daya pikir dan daya fisik yang dimiliki individu, perilaku dan sifatnya ditentukan oleh keturunan dan lingkungannya, sedangkan prestasi kerja dimotivasi oleh keinginan untuk memenuhi kepuasannya. (Widodo, 2015:32). Sutrisno (2009:3), Sumber daya yang dibutuhkan untuk menjalankan organisasi tidak dapat dilihat sebagai bagian yang berdiri sendiri, tetapi harus dilihat sebagai satu kesatuan yang tangguh membentuk suatu sinergi. Dalam hal ini peran sumber daya manusia sangat menentukan.

Sumber daya manusia merupakan satusatunya sumber daya yang memiliki akal perasaan, keinginan, keterampilan, pengetahuan, dorongan, daya, dan karya (rasio, rasa, dan karsa). Semua potensi sumber daya manusia tersebut berpengaruh terhadap upaya organisasi dalam mencapai tujuan. Betapapun majunya teknologi, perkembangan informasi, tersedianya modal dan memadainya bahan, jika tanpa sumber daya manusia sulit bagi organisasi itu untuk mencapai tujuannya.

Menurut Werther dan Davis (1996) dalam Sutrisno (2009:4) menyatakan bahwa sumber daya manusia adalah pegawai yang sipa, mampu, dan siaga dalam mencapai tujuantujuan organisasi. Sebagaimana dikemukakan bahwa dimensi pokok sisi sumber daya adalah kontribusinya terhadap organisasi, sedangakan dimensi pokok manusia adalah perlakuan kontribusi terhadapnya yang pada gilirannya akan menentukan kualitas dan kapabilitas hidupnya.

Menurut Ndraha (1999) dalam Sutrisno (2009:4), sumber daya manusia berkualitas tinggi adalah sumber daya manusia yang mampu menciptakan bukan saja nilai komparatif tetapi juga nilai kompetitif-generatif-inovatif dengan menggunakan energi tertinggi seperti: intelligence, creativity dan imagination; tidak lagi semata-mata menggunakan energi kasar, seperti bahan mentah, lahan, air tenaga otot, dan sebagainya.

Sumber daya manusia diartikan sebagai sumber dari kekuatan yang berasal dari manusia-manusia yang dapat didayagunakan oleh organisasi. Dengan berpegang pada pengertian tersebut, sumber daya manusia adalah manusia bersumber daya dan merupakan kekuatan (power). Dari berbagai pengertian tersebut maka dapat diartikan bahwa sumber daya manusia adalah sumber daya yang memiliki potensi, kontribusi dan peran yang berpengaruh terhadap upaya pencapaian tujuan organisasi.

\subsection{Manajemen Sumber Daya Manusia}

Munurut Hasibuan (2014), Manajemen adalah ilmu mengatur proses pemanfaatan sumber daya manusia dan sumber-sumber lainnya secara efektif dan efisien untuk mencapai suatu tujuan tertentu. Manajemen merupakan alat untuk mencapai tujuan yang diinginkan. Manajemen yang baik akan 
memudahkan terwujudnya tujuan organisasi, karyawan dan masyarakat. Dengan manajemen daya guna dan hasil guna unsur-unsur manajemen akan adapat ditingkatkan. Adapun unsur-unsur manajemen itu terdiri dari $6 \mathrm{M}$ yaitu: man, money, method, machines, materials, dan market.

Sesungguhnya manajemen berasal dari kata to manage yang artinya mengatur. Sehingga timbul pertanyaan tentang apa yang diatur, apa tujuannya diatur, mengapa harus diatur, siapa yang mengatur, dan bagaimana mengaturnya. (Hasibuan, 2014).

1. Yang diatur adalah semua unsur manajemen.

2. Tujuan diatur adalah agar $6 \mathrm{M}$ lebih berdaya guna dan berhasil guna dalam mewujudkan tujuan.

3. Harus diatur supaya $6 \mathrm{M}$ itu bermanfaat optimal, terkoordinasi dan terintegrasi dengan baik dalam menunjang terwujudnya tujuan organisasi.

4. Yang mengatur adalah pimpinan dengan kepemimpinannya yaitu pimpinan puncak, manajer madya, dan supervisi.

5. Bagaimana mengaturnya adalah melakukan kegiatan urut-urutan fungsi manajemen tersebut.

Dasar-dasar manajemen menurut Hasibuan (2014), adalah sebagai berikut:

1. Adanya kerjasama diantara sekelompok orang dalam ikatan formal;

2. Adanya tujuan bersama serta kepentingan yang sama yang akan dicapai;

3. Adanya pembagian kerja, tugas, dan tanggung jawab yang teratur;

4. Adanya hubungan formal dan ikatan tata tertib yang baik;

5. Adanya sekelompok orang dan pekerjaan yang akan dikerjakan;

6. Adanya human organization .
Manajemen sumber daya manusia dipandang sebagai peranan yang cukup penting di organisasi. Manajemen SDM adalah suatu proses yang mencakup evaluasi terhadap kebutuhan SDM, mendapatkan orang-orang untuk memenuhi kebutuhan itu, dan mengoptimalkan pendayagunaan sumber daya yang penting tersebut dengan cara memberikan insentif dan penugasan yang tepat, agar sesuai dengan kebutuhan dan tujuan organisasi di mana SDM itu berada.

Menurut Gerry Dessler (2011:31) dalam Widodo (2015:2) berpendapat bahwa "Human resource management is the process acquiring, training, appraising, and compensating employees, and attending to their labor relations, health and safety and fairness concerns". Manajemen sumber daya manusia adalah proses memperoleh, melatih, menilai, dan memberikan kompensasi kepada karyawan, memperhatikan hubungan kerja mereka, kesehatan, keamanan dan masalah keadilan.

Menurut pendapat Edwin B. Hippo (1981:16) dalam Widodo (2015:2-3), yaitu "Personal management is the planning organizing directing, and controlling of the procurement, development, compensation, integration, maintenance, and separation of human resources to the and that individual, organizational, and societal objectives are accomplished'. Manajemen personalia adalah perencanaan, pengorganisasian, pengarahan, dan pengendalian dari pengadaan, pengembangan, kompensasi, pengintegrasian, pemeliharaan dan pemberhentian karyawan, dengan maksud terwujudnya tujuan perusahaan, individu, karyawan dan masyarakat.

Menurut Mathis \& Jackson (2012:5) dalam Widodo (2015:3), Manajemen sumber daya manusia (MSDM) dapat diartikan sebagai ilmu dan seni yang mengatur hubungan dan peranan tenaga kerja agar efektif dan efisien dalam penggunaan kemampuan manusia agar 
dapat mencapai tujuan di setiap perusahaan. Menurut Noe, dkk (2008:4) dalam Widodo (2015:3), manajemen sumber daya manusia (MSDM) adalah kebijakan, praktik, dan sistem yang mempengaruhi kebiasaan, sikap, dan performa seorang karyawan.

Menurut Bohlander dan Snell (2010:4) dalam Widodo (2015:3-4), manajemen sumber daya manusia (MSDM) yakni suatu ilmu yang mempelajari bagaimana memberdayakan karyawan dalam perusahaan, membuat pekerjaan, kelompok kerja, mengembangkan para karyawan yang mempunyai kemampuan, mengidentifikasikan suatu pendekatan untuk dapat mengembangkan kinerja karyawan dan memberikan imbalan kepada mereka atas usahanya dalam bekerja. Dari berbagai pendapat diatas dapat didefinisikan bahwa manajemen sumber daya manusia adalah suatu ilmu yang digunakan untuk mengatur orang atau karyawan atau tenaga kerja sesuai dengan tujuan organisasi yang diharapkan. Menurut Widodo (2015:4), manajemen sumber daya manusia wajib diterapkan di sebuah organisasi agar organisasi tersebut dapat terus berkembang karena keberhasilan suatu organisasi juga bergantung pada sumber daya manusia di dalam organisasi tersebut.

Peranan manajemen sumber daya manusia yang dikemukakan oleh Hasibuan (2005:34) dalam Widodo (2015:4) antara lain:

1. Menetapkan jumlah, kualitas, dan penetapan tenaga kerja yang efektif sesuai dengan kebutuhan perusahaan berdasarkan job description, job specification, dan job evaluation.

2. Menetapkan penarikan, seleksi, dan penempatan karyawan berdasarkan atas the right man in the right job.

3. Menetapkan program kesejahteraan, pengembangan, promosi, dan pemberhentian.

4. Meramalkan penawaran dan permintaan sumber daya manusia pada masa yang akan datang.

5. Memperkirakan keadaan perekonomian pada umumnya dan perkembangan perusahaan pada khususnya.

6. Memonitor dengan cermat undangundang perubahan dan kebijaksanaan pemberian bebas jasa perusahaanperusahaan sejenis.

7. Memonitor kemajuan teknik dan perkembangan serikat buruh.

8. Melaksanakan pendidikan, latihan, dan penilaian prestasi karyawan.

9. Mengatur mutasi karyawan baik vertical maupun horizontal.

10. Mengatur pensiun, pemberhentian, dan pesangon.

Salah satu kegiatan yang penting dalam manajemen SDM adalah menentukan kebutuhan SDM bagi organisasi dan menyusun rencana kegiatan untuk dapat memenuhi kebutuhan tersebut. (Widodo, 2015: 32). Menurut Widodo (2015: 35), perencanaan SDM adalah menghubungkan SDM yang ada untuk kebutuhan perusahaan pada masa yang akan datang untuk menghindari mismanajemen dan tumpang tindih dalam pelaksanaan tugasnya.

Tujuan perencanaan SDM adalah untuk menjamin penggunaan yang optimal terhadap SDM pada organisasi saat ini, menyediakan SDM yang dibutuhkan oleh organisasi dimasa mendatang baik dalam hal kualitas maupun kuantitas. (Widodo, 2015). Fungsi perencanaan SDM adalah memformulasikan dan mengintegrasikan rencana SDM dengan rencana organisasi, mengkaji faktor sosial, teknologi, dan yang lainnya sehingga mempunyai dampak terhadap pekerjaan dan individu terhadap kebutuhan dan ketersediaan SDM bagi organisasi; membuat prediksi SDM, medukung kegiatan pengadaan, alokasi, kompetensi dan pengembangan SDM. (Widodo, 2015).

Tujuan manajemen sumber daya manusia 
menurut Cushway dalam Sutrisno (2009:7) meliputi:

1. Memberi pertimbangan manajemen dalam membuat kebijakan SDM untuk memastikan bahwa organisasi memiliki pekerja yang bermotivasi dan berkinerja yang tinggi, memiliki pekerja yang selalu siap mengatasi perubahan dan memenuhi kewajiban pekerjaan secara legal;

2. Mengimplementasikan dan menjaga semua kebijakan dan prosedur SDM yang memungkinkan organisasi mampu mencapai tujuannya;

3. Membantu dalam pengembangan arah keseluruhan organisasi dan strategi, khususnya yang berkaitan dengan implikasi SDM;

4. Memberi dukungan dan kondisi yang akan membantu manajer lini mencapai tujuannya

5. Menangani berbagai krisis dan situasi sulit dalam hubungan antar pekerja untuk meyakinkan bahwa mereka tidak menghambat organisasi dalam mencapai tujuannya;

6. Menyediakan media komunikasi antara pekerja dan manajemen organisasi;

7. Bertindak sebagai pemelihara standar organisasional dan nilai dalam manajemen SDM.

Sementara itu, menurut Schuler et al dalam Sutrisno (2009:7), manajemen SDM memiliki tiga tujuan utama, yaitu:

1. Memperbaiki tingkat produktivitas;

2. Memperbaiki kualitas kehidupan kerja;

3. Meyakinkan organisasi telah memenuhi aspek-aspek legal.

\subsection{Mutu Pendidikan Perguruan Tinggi}

Sudarsana, et al (2014:1) dalam Buku Kebijakan Mutu Institut Hindu Dharma Negeri Denpasar, pendidikan adalah usaha sadar dan terencana untuk mewujudkan suasana belajar dan proses pembelajaran agar peserta didik secara aktif mengembangkan potensi dirinya untuk memiliki pengendalian diri, kepribadian, kecerdasan, akhlak mulia, dan keterampilan yang diperlukan dirinya, masyarakat, bangsa, dan negara. Pendidikan dapat menyiapkan sumber daya manusia berkualitas yang siap mengisi pembangunan dan memajukan bangsa.

Pendidikan tinggi adalah jenjang pendidikan formal setelah pendidikan menengah. Pendidikan tinggi menyelenggarakan kegiatan pembelajaran, penelitian, dan pengabdian kepada masyarakat dengan menjunjung tinggi nilai-nilai persatuan bangsa sehingga mampu menghasilkan lulusan yang kompeten. Salah satu upaya untuk peningkatan mutu perguruan tinggi adalah mengembangkan Penjaminan Mutu di perguruan tinggi. Dengan Penjaminan Mutu diharapkan tumbuh budaya mutu.

Model manajemen pelaksanaan Sistem Penjaminan Mutu Internal dirancang, dilaksanakan, dan ditingkatkan mutunya berkelanjutan dengan berdasarkan pada model PDCA (Plan, Do, Check, Action). Dengan model ini, maka akan ditetapkan terlebih dahulu tujuan yang ingin dicapai melalui strategi dan serangkaian aktivitas yang tepat. Kemudian, terhadap pencapaian tujuan melalui strategi dan aktivitas tersebut akan selalu dimonitor secara berkala, dievaluasi, dan dikembangkan ke arah yang lebih baik secara berkelanjutan. Dengan model manajemen PDCA, maka secara berkala harus melakukan proses evaluasi diri untuk menilai kinerja unitnya sendiri dengan menggunakan standar dan prosedur yang telah ditetapkan. Hasil evaluasi diri akan dilaporkan kepada pimpinan unit, seluruh staf pada unit bersangkutan, dan kepada pimpinan institut. Terhadap hasil evaluasi diri pimpinan unit dan pimpinan institut akan membuat keputusan tentang langkah atau tindakan yang harus dilakukan untuk memperbaiki dan meningkatkan mutu. (Sudarsana, et al, 2014) 
Sudarsana, et al (2014) dalam Buku Kebijakan Mutu Institut Hindu Dharma Negeri Denpasar, dijabarkankan beberapa prinsip yang melandasi pola pikir dan pola tindak semua prilaku menajemen kendali mutu berbasis PDCA diantaranya:

a. Quality first (Mengutamakan mutu dan kualitas)

Semua pikiran dan tindakan pengelola pendidikan harus memprioritaskan mutu dan kualitas.

b. Stakeholder

Semua pikiran dan tindakan pengelola pendidikan harus ditujukan untuk kepuasan semua pemangku kepentingan.

c. Speak with data

Setiap orang pelaksana harus melakukan tindakan dan mengambil keputusan berdasarkan analisis data yang diperolehnya terlebih dahulu, bukan berdasarkan pengandaian yang harus dipuaskan.

d. Upstream management (pengambilan keputusan berdasarkan SHIP Approach)

Semua pengambilan keputusan dilakukan secara sistemik, holistic, interdisipliner dan partisipatori, bukan otoritatif.

Implementasi model PDCA dalam pengelolaan penjaminan mutu diatur dalam empat tahap sebagai berikut:

a. Perencanaan.

Dalam tahap ini pimpinan perguruan tinggi menetapkan perencanaan (plan) berupa tujuan yang akan dicapai melalui strategi yang dituangkan dalam kebijakan mutu dengan berbagai standar mutu serta serangkaian aktivitas dalam rangka penyusunan sistem penjaminan mutu internal.

b. Pelaksanaan.

Dalam tahap ini seluruh tingkatan unit kerja baik akademik maupun non akademik yang meliputi tingkat institut, lembaga, fakultas, pascasarjana, jurusan, prodi, laboratorium, dan unit pelaksana teknis lainnya harus melaksanakan (do) aktivitas sesuai dengan standar mutu, standar operational prosedur (SOP) dan formulir (borang/perform) yang ditetapkan.

c. Pengendalian.

Dalam tahapini seluruh unit kerja harus melakukan evaluasi (check) untuk menilai kinerja unitnya setiap akhir semester dengan menggunakan prosedur yang telah ditetapkan.

d. Pengembangan.

Berdasarkan rekomendasi dari tim auditor, pimpinan unit terkait dan pimpinan perguruan tinggi membuat keputusan tentang langkah atau tindak lanjut yang harus dilakukan. Bila hasil audit menunjukkan bahwa standar mutu yang ditetapkan belum atau tidak tercapai, maka harus segera dilakukan kajian lebih lanjut kemudian diintegrasikan pada standar mutu berikutnya. Bila hasil audit telah mencapai standar, maka proses perencanaan pada siklus berikutnya harus ditingkatkan sehingga menghasilkan kaizen atau peningkatan mutu berkelanjutan (continuous improvement).

Keempat tahapan tersebut dimaksudkan untuk menjamin bahwa setiap aktivitas penyelenggaraan pendidikan di Perguruan Tinggi terjamin mutunya dan setiap unit kerja selalu melaksanakan evaluasi untukmenemukan kekuatan dan kelemahannya sehingga dapat dilakukan perubahan ke arah peningkatan mutu secara berkelanjutan. (Sudarsana, et al, 2014)

Menurut Sudarsana, et al (2014) dalam Buku Kebijakan Institut Hindu Dharma Negeri Denpasar, standar mutu mencakup aspek kegiatan akademik dan non akademik yang 
terdiri dari tujuh standar mutu BAN-PT yang diintegrasikan dengan Standar Nasional Pendidikan Tinggi seperti diamanatkan oleh UU No 12 Tahun 2012 yang mencakup:

A. Standar: Visi, Misi, Tujuan, Sasaran, Strategi

Berisi kerangka dasar yang memberi arahan pada program studi dalam perumusan dan pelaksanaan tugas pokoknya. Kerangka dasar dimaksud meliputi visi, misi, tujuan, sasaran dan strategi pencapaiannya. Kerangka dasar di atas dijabarkan oleh setiap program studi berdasarkan pada rumusan fakultas dan institut, sehingga standar dimaksud berkontribusi pada pencapaian visi institusi secara keseluruhan.

B. Standar Tata Pamong, Kepemimpinan, Sistem Pengelolaan, dan Penjaminan Mutu

Standar ini berisi kaidah-kaidah pokok yang mengatur bagaimana sebuah unit/program studi dikelola berdasarkan pada prinsip-prinsip good university governance (GUG) yang mengedepankan efektifitas, efisiensi, transparansi, dan akuntabilitas.

C. Standar Mahasiswa dan Lulusan Meliputi sejumlah ukuran pokok yang dapat menjadi indikator berjalannya suatu proses pembelajaan secara efektif dan sekaligus menjadi cerminan dari kualitas lulusan. Standar ini harus dirumuskan pada semua level pengelolaan akademik, dengan prinsip yang berada pada level tertinggi menjadi ukuran minimal.

D. Standar Sumber Daya Manusia (SDM)

SDM yang mendukung proses akademik dan administrasi harus memenuhi syarat kualifikasi minimal. Bagi para dosen pemenuhan kualifikasi pendidikan minimal, jabatan fungsional dan profesi harus menjadi yang utama. Disamping itu, rasio jumlah dosen terhadap mahasiswa dan sebaran perbidang ilmu juga menjadi standar yang harus diperhatikan. Selanjutnya, tenaga kependidikan harus memiliki kompetensi yang mendukung berjalannya seluruh proses administrasi secara efektif dan efisien.

E. Standar Kurikulum, Pembelajaran dan Suasana Akademik Input, proses dan atmosfir proses pembe-lajaran harus mendukung terbentuknya output/lulusan. Kurikulum harus dikembangkan berdasarkan paradigma kesatuan ilmu yang disesuaikan dengan dinamika masyarakat. Proses akademik dilakukan dengan memperhatikan kaidah-kaidah ilmu pendidikan dengan dukungan suasana akademik yang kondusif bagi tercapainya hasil maksimal.

F. Standar Pembiayaan, Prasarana, Sarana, dan Sistem Informasi Standar pembiayaan harus didasarkan pada kebutuhan unit yang dicerminkan lewat dokumen perencanaan yang memuat target kinerja.

G. Standar Penelitian, Pengabdian Pada Masyarakat, dan Kerjasama

Penelitian dan pengabdian pada masyarakat dilakukan dengan berasaskan keadilan keterlibatan dosen melalui mekanisme kompetisi. Kerjasama dibangun atas dasar kesepahaman untuk mencapai manfaat bagi kedua belah pihak. 


\subsection{Manajemen Sumber Daya Manusia dalam Peningkatan Mutu}

Perguruan tinggi sebagai suatu lembaga pendidikan formal, dalam penyelenggaraan pendidikannya sangat diperlukan adanya peningkatan kualitas mutu. Pendidikan dapat dikatakan bermutu dan berkualitas jika semua aspeknya memenuhi standar. Manajemen dapat dijadikan alat atau cara untuk mencapai peningkatan kualitas mutu tersebut dengan salah satu pilarnya adalah sumber daya manusia.

Manajemen sumber daya manusia sangat penting dalam meningkatkan kualitas mutu pendidikan. Hal ini didasarkan dalam suatu lembaga pendidikan bisa berkembang dan maju dengan dukungan dari sumber daya manusia didalamnya. Sehingga setiap lembaga pendidikan yang ingin maju dan berkembang harus memperhatikan sumber daya manusianya dan mengelolanya dengan baik dan terwujud pendidikan yang berkualitas dan bermutu.

Peningkatan mutu pendidikan sangat ditentukan oleh pimpinan lembaga pendidikan dalam mengelola sumber daya manusianya dalam hal ini tenaga pendidik dan kependidikan. Dalam manajemen sumber daya manusia, pimpinan perguruan tinggi menjadi kunci dalam peningkatan mutu pendidikan. Pimpinan perguruan tinggi dituntut untuk selalu mengembangkan sumber daya manusia untuk menciptakan pendidikan yang bermutu.

Pentingnya manajemen sumber daya manusia dalam meningkatkan kualitas pendidikan, didasari oleh (Zulfa, 2013):

a. Sumber daya manusia atau tenaga kerja merupakan faktor sentral dalam pendidikan, mengingat perannya yang sangat penting dalam meningkatkan kualitas pendidikan.

b. Dengan pemanfaatan sumber daya manusia oleh manajer dalam suatu organisasi secara efektif dan efisien, akan mengoptimalkan pencapaian tujuan organisasi dan pemanfaatan sumber daya manusia dimulai dari melakukan perencanaan yang tepat, pengorganisasian yang mantap, penyusunan staf yang tepat dan profesional, pengarahan dan pengawasan yang terkendali dengan baik akan menjamin berfungsinya proses manajerial.

c. Manajemen sumber daya manusia termasuk salah satu bagian dari manajemen pendidikan secara keseluruhan, dan manajemen sumber daya manusia menduduki tempat yang sangat penting. Dikatakan demikian karena sumber daya manusia dalam hal ini tenaga pendidik adalah faktor sentral dalam pendidikan.

d. Sumber daya manusia merupakan faktor penting bagi keberhasilan suatu lembaga pendidikan, untuk itu sumber daya manusia perlu dikelola dengan sebaik-baiknya melalui manajemen sumber daya manusia. Karena melalui usaha-usaha dan kreativitas sumber daya manusia, organisasi dapat menghasilkan suatu produk dan jasa yang berkualitas.

\section{KESIMPULAN}

Manajemen sumber daya manusia merupakan hal yang sangat penting didalam meningkatkan mutu pendidikan. Perguruan tinggi dapat maju dan berkembang dengan dukungan dari sumber daya manusia yang berkualitas. Oleh sebab itu, setiap perguruan tinggi yang ingin maju dan berkembang, maka harus memperhatikan sumber daya manusia dan mengelola sebaik-baiknya sehingga terwujud pendidikan yang bermutu.

Dalam peningkatan mutu, sumber daya manusia menjadi berpengaruh dikarenakan sumber daya manusia dalam hal ini tenaga pendidik merupakan faktor sentral dalam pendidikan, mengingat perannya yang sangat penting dalam meningkatkan kualitas pendidikan. Dengan pemanfaatan sumber daya 
manusia oleh manajer (pimpinan) dalam suatu organisasi atau lembaga pendidikan secara efektif dan efisien, akan mengoptimalkan pencapaian tujuan lembaga pendidikan tersebut, dan pemanfaatan sumber daya manusia dimulai dari melakukan perencanaan yang tepat, pengorganisasian yang mantap, penyusunan staf yang tepat dan profesional, pengarahan dan pengawasan yang terkendali dengan baik akan menjamin berfungsinya proses manajerial.

Sumber daya manusia merupakan faktor penting bagi keberhasilan suatu lembaga pendidikan, untuk itu sumber daya manusia perlu dikelola dengan sebaik-baiknya melalui manajemen sumber daya manusia.

\section{DAFTAR PUSTAKA}

Hasibuan, Malayu S.P. 2014. Manajemen Sumber Daya Manusia. Jakarta: PT. Bumi Aksara

Kesit, Bambang. 2009. Manajemen SDM Dosen dalam Meningkatkan Mutu Pendidikan di Perguruan Tinggi, (http:/ /www.bambangkesit.staff.uii.ac.id, Diakses pada tanggal 1 Agustus 2015)
Putra, Komang. 2014. Sertifikasi ISO Terhadap Kwalitas Perguruan Tinggi, (http://komangputra.com, Diakses pada tanggal 1 Agustus 2015)

Susanti, Tris. 2013. Pentingnya MSDM Dalam Meningkatkan Kualitas Pendidikan, (http://www.hrcentro.com, Diakses pada tanggal 29 Juli 2015)

Sutrisno, Edy. 2009. Manajemen Sumber Daya Manusia. Jakarta: Kencana Prenada Media Group

Sudarsana, I Ketut, et al. 2014. Kebijakan Mutu Institut Hindu Dharma Negeri Denpasar. Denpasar:Lembaga Penjaminan Mutu

Widodo, Suparno Eko. 2015. Manajemen Pengembangan Sumber Daya Manusia. Yogyakarta: Pustaka Pelajar

Zulfa, Marrisa. 2013. Pentingnya MSDM Dalam Meningkatkan Kualitas Pendidikan, (http://marissazulfa. wordpress.com, Diakses pada tanggal 1 Agustus 2015) 